\title{
VALIDASI KONDISI PERAIRAN BERDASARKAN NILAI TOTAL SUSPENDED SOLID (TSS) MENGGUNAKAN DATA CITRA SATELIT LANDSAT 8 DAN DATA INSITU (STUDI KASUS : PANTAI TIMUR SURABAYA)
}

\author{
Teguh Hariyanto ${ }^{1}$, Cherie Bhekti Pribadi, Herfina Elya \\ ${ }^{1}$ Departemen Teknik Geomatika, FTSLK-ITS, Kampus ITS Sukolilo, Surabaya, 60111, Indonesia \\ Email: teguh_hr@geodesy.its.ac.id
}

\begin{abstract}
Abstrak
Perairan Pantai Timur Surabaya termasuk perairan yang tercemar berat oleh limbah domestik, limbah industri, limbah pertanian, dan limbah. Kondisi ini menyebabkan terganggunya kelangsungan hidup biota yang ada disekitarnya, seperti pada perikanan, ekosistem pesisir, dan laut, yang berdampak lebih luas terhadap penurunan pendapatan masyarakat pesisir yang menggantungkan hidupnya pada produktivitas hayati di wilayah pesisir dan pantai. TSS (Total Suspended Solid) merupakan salah satu parameter penentu kualitas air. Metode penginderaan jauh dengan citra satelit dapat menjadi solusi untuk melakukan penelitian TSS. Data yang digunakan dalam penelitian ini yaitu data primer berupa data insitu pada tanggal 17 Maret 2017 dan data sekunder berupa citra satelit Landsat-8 tahun 2013, 2014, 2015, 2016, 2017. Metode yang digunakan dalam penelitian ini didasarkan pada pengolahan citra satelit Landsat 8 menggunakan 3 algoritma yaitu, algoritma Budima, algoritma Parwati, algoritma Laili. Dilakukan korelasi linier antara data citra dan insitu. Data hasil korelasi terbaik yaitu algoritma Budiman dengan nilai koefisien determinasi sebesar 0,853. Hasil pengolahan data didapatkan nilai TSS bervariasi antara 1-192 mg/L. Status mutu air perairan Pantai Timur Surabaya berdasarkan Keputusan Menteri Lingkungan Hidup No. 115 tahun 2003 pada Pantai Timur Surabaya rata-rata berada pada nilai $0 \leq$ indeks pencemaran $\leq 1$ yang berarti memenuhi baku mutu (kondisi baik).
\end{abstract}

Kata kunci: TSS, Citra Landsat 8, Data Insitu.

\section{Abstract}

East Coast waters of Surabaya include waters heavily polluted by domestic waste, industrial waste, agricultural waste, and pond waste. This condition causes disruption to the survival of nearby biota, such as fisheries, coastal ecosystems, and marine, which have a more widespread impact on the declining income of coastal communities that rely on biodiversity in coastal areas. TSS (Total Suspended Solid) is one of the determinants of water quality. The data used in this research are primary data on March 17, 2017 and secondary data in the form of Landsat-8 satellite imagery in 2013, 2014, 2015, 2016, 2017. The method used based on Landsat 8 satellite image processing Using 3 algorithms, Budiman algorithm, Parwati algorithm, Laili algorithm, then viewed linear correlation between image data and insitu using correlation test. The best correlation result data is Budiman with coefficient of determination equal to 0,853 . Results of data processing obtained TSS value varies between 1-192 mg / L. Water quality status of Surabaya East Coast waters based on Decree of the Minister of Environment No. 115 of 2003 on the East Coast of Surabaya is on average $0 \leq$ pollution index $\leq 1$ which means it meets the quality standard (good condition).

Keywords: TSS, Landsat 8 Sattelite Imagery, Insitu Data

\section{PENDAHULUAN}

Jawa timur memiliki panjang pantai sekitar kurang lebih $2.128 \mathrm{~km}$ yang secara umum dapat dikelompokkan menjadi kawasan pesisir utara, pesisir timur, pesisir selatan. Kawasan pesisir utara dan pesisir timur merupakan pusat perekonomian dan persebaran penduduk di Jawa Timur, sehingga terjadinya potensi kerusakan lingkungan lebih tinggi dibandingkan pesisir selatan. Perairan pesisir timur termasuk perairan yang tercemar berat oleh limbah domestik, limbah industri, limbah pertanian, dan limbah tambak (Siagian, 2008).

Pencemaran laut merupakan salah satu masalah yang mengancam bumi ini. Dilihat dari karakteristrik limbah cair di Jawa Timur, diketahui volume limbah cair tertinggi berasal dari sumber limbah domestik sekitar 84,4\% dari total volume sumber pencemaran (Wijaya dan Kartika, 2004). $\mathrm{Hal}$ ini memberikan pengaruh yang merugikan bagi manusia dan lingkungan air. Tingkat pencemaran laut ini telah menjadi ancaman serius bagi laut 
Indonesia dengan segala potensinya. Komponenkomponen yang menyebabkan pencemaran laut seperti partikel kimia, limbah industri, limbah pertambangan, limbah pertanian dan perumahan, kebisingan, atau penyebaran organisme asing di dalam laut yang berpotensi memberi efek buruk terhadap kestabilan ekosistem perairan Pantai Timur Surabaya. Persoalan air yang paling besar adalah masalah pencemaran air. Pencemaran air adalah suatu perubahan keadaan di suatu tempat penampungan air seperti danau, lautan, dan air tanah akibat aktivitas manusia. Perubahan ini mengakibatkan menurunnya kualitas air hingga ke tingkat yang membahayakan sehingga air tidak bisa digunakan sesuai dengan peruntukannya. Kondisi ini menyebabkan terganggunya kelangsusngan hidup biota yang ada disekitarnya, seperti pada perikanan, ekosistem pesisir, dan laut (mangrove, padanglamun, terumbu karang), yang berdampak lebih luas terhadap penurunan pendapatan masyarakat pesisir yang menggantungkan hidupnya pada produktivitas hayati di wilayah pesisir dan pantai (Saeni, 2008).

Total Suspended Solid (TSS) merupakan parameter penentu kualitas badan air. Total suspended solid (TSS) adalah bahan-bahan tersuspensi (diameter > $1 \mu \mathrm{m})$ yang tertahan pada saringan miliopore dengan diameter pori $0,45 \mu \mathrm{m}$. SS merupakan zatzat padat yang berada dalam suspensi, yang dapat dibedakan menurut ukurannya sebagai partikel tersuspensi koloid (partikel koloid) dan partikel tersuspensi biasa (partikel tersuspensi). TSS terdiri dari lumpur dan pasir halus serta jasad-jasad renik (Effendi,2003). Penyebab TSS di perairan yang utama adalah kikisan tanah atau erosi tanah yang terbawa ke badan air. Konsentrasi TSS apabila terlalu tinggi menghambat penetrasi cahaya ke dalam air dan mengakibatkan terganggunya proses fotosintesis (Lestari, 2009). Perkembangan teknologi khususnya dalam penginderaan jauh menjadikan pelaksanaan pemetaan sebaran TSS menjadi efisien. Metode dalam penelitian ini menggunakan citra satelit landsat 8 dan data insitu.

\section{METODE}

Penelitian ini menggunakan data berupa Citra Satelit Landsat 8 bulan November 2013, September 2014, September 2015, Juli 2016,
Maret 2017, Peta Rupa Bumi Indonesia skala 1:25.000, Data sampel air perairan Pantai Timur Surabaya pada bulan Maret 2017.

Metode pengolahan data pada penelitian ini adalah sebagai berikut:

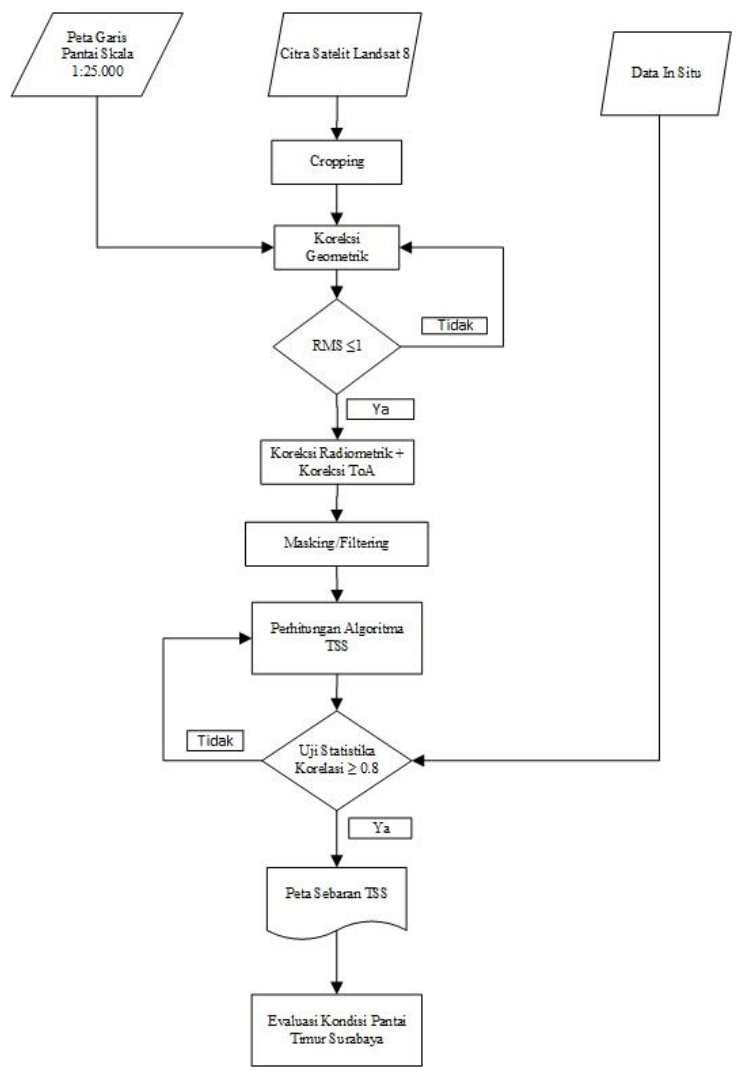

Gambar 1. Diagram Alir Penelitian

\section{HASIL DAN PEMBAHASAN}

Perbandingan Nilai TSS Citra 17 Maret 2017 menggunakan 3 algoritma dengan TSS In Situ

Perbandingan TSS Citra 17 Maret 2017 menggunakan Algoritma TSS Parwati (2006), Algoritma TSS Budiman (2004), dan Algoritma TSS Laili (2015) dengan TSS In Situ.

Tabel 3. Nilai Konsentrasi TSS Menggunakan 3 Algoritma Berbeda

\begin{tabular}{ccccccc}
\multicolumn{8}{c}{ Koordinat Geografis } & \begin{tabular}{c} 
TSS \\
In \\
\cline { 2 - 6 } No
\end{tabular} & $\mathrm{X}$ & $\mathrm{Y}$ & $\begin{array}{c}\text { TSS } \\
\text { (Laili) } \\
\mathrm{mg} / \mathrm{l}\end{array}$ & $\begin{array}{c}\text { TSS } \\
\text { (Parwat) } \\
\mathrm{mg} / \mathrm{l}\end{array}$ & $\begin{array}{c}\text { TSS } \\
\text { (Budi } \\
\text { man) } \\
\mathrm{mg} / \mathrm{l}\end{array}$ \\
\hline 1 & 697850 & 9202332 & 40 & 15,74 & 14,20 & 21,91 \\
2 & 698856 & 9200711 & 52 & 16,62 & 17,65 & 25,53 \\
3 & 699784 & 9199212 & 128 & 18,22 & 25,99 & 33,49 \\
4 & 701244 & 9198726 & 160 & 19,62 & 42,31 & 47,15 \\
5 & 702238 & 9198053 & 160 & 20,04 & 49,83 & 52,90 \\
6 & 703073 & 9198741 & 18 & 14,31 & 11,31 & 18,67
\end{tabular}




\begin{tabular}{|c|c|c|c|c|c|c|}
\hline \multirow{2}{*}{ No } & \multicolumn{2}{|c|}{ Koordinat Geografis } & \multirow{2}{*}{$\begin{array}{l}\text { TSS } \\
\text { In } \\
\text { Situ } \\
\mathrm{mg} / \mathrm{l}\end{array}$} & \multirow{2}{*}{$\begin{array}{l}\text { TSS } \\
\text { (Laili) } \\
\mathrm{mg} / \mathrm{l}\end{array}$} & \multirow{2}{*}{$\begin{array}{c}\text { TSS } \\
\text { (Parwat) } \\
\mathrm{mg} / \mathrm{l}\end{array}$} & \multirow{2}{*}{$\begin{array}{l}\text { TSS } \\
\text { (Bud } \\
\text { man) } \\
\mathrm{mg} / \mathrm{l}\end{array}$} \\
\hline & $x$ & Y & & & & \\
\hline 7 & 702163 & 9199281 & 18 & 13,32 & 7,58 & 14,10 \\
\hline 8 & 700784 & 9199842 & 24 & 15,15 & 13,84 & 21,52 \\
\hline 9 & 696669 & 9202783 & 30 & 17,99 & 15,62 & 23,42 \\
\hline 10 & 697194 & 9202399 & 34 & 16,05 & 15,01 & 22,78 \\
\hline 11 & 697735 & 9201667 & 28 & 17,64 & 20,68 & 28,52 \\
\hline 12 & 698191 & 9201065 & 24 & 17,76 & 20,40 & 28,26 \\
\hline 13 & 698514 & 9200302 & 30 & 17,25 & 15,53 & 23,33 \\
\hline 14 & 699033 & 9199704 & 24 & 17,61 & 19,92 & 27,79 \\
\hline 15 & 699319 & 9198951 & 60 & 20,69 & 59,74 & 60,08 \\
\hline 16 & 700162 & 9198583 & 154 & 21,71 & 103,89 & 88,61 \\
\hline 17 & 700974 & 9198342 & 176 & 22,04 & 85,09 & 77,02 \\
\hline 18 & 701602 & 9197914 & 192 & 21,94 & 70,87 & 67,74 \\
\hline 19 & 702226 & 9197527 & 184 & 21,47 & 65,56 & 64,14 \\
\hline 20 & 702672 & 9197961 & 24 & 18,36 & 31,01 & 37,91 \\
\hline 21 & 702549 & 9198594 & 24 & 14,08 & 9,25 & 16,21 \\
\hline 22 & 702041 & 9199100 & 24 & 14,44 & 11,58 & 18,99 \\
\hline 23 & 701365 & 9199616 & 22 & 14,88 & 11,81 & 19,25 \\
\hline 24 & 700498 & 9199447 & 30 & 17,08 & 21,92 & 29,72 \\
\hline 25 & 699928 & 9199964 & 24 & 16,38 & 18,41 & 26,30 \\
\hline 26 & 699445 & 9200494 & 30 & 16,82 & 18,13 & 26,01 \\
\hline 27 & 698983 & 9201033 & 28 & 16,59 & 18,08 & 25,96 \\
\hline 28 & 698489 & 9201559 & 34 & 16,08 & 15,50 & 23,30 \\
\hline 29 & 697906 & 9202096 & 38 & 16,11 & 15,54 & 23,34 \\
\hline 30 & 696925 & 9202778 & 46 & 15,74 & 13,04 & 20,63 \\
\hline
\end{tabular}

\section{Validasi Hasil Pengolahan Citra dengan Data} Lapangan

Uji validasi dilakukan menggunakan data Citra Landsat 8 dan data insitu pada tanggal 17 Maret 2017. Pada uji validasi dilakukan perhitungan korelasi dengan membandingkan data olahan citra dengan data hasil ground truth TSS yang ada di lapangan. Hal ini digunakan untuk melihat sejauh mana kedekatan atau kebaikan data citra yang digunakan.

Pada uji validasi ini dihasilkan nilai koefisien determinasi sebagai berikut:

a. Uji korelasi data lapangan TSS (Total Suspended Solid) dengan data hasil olahan TSS (Total Suspended Solid) Citra Landsat 8 menggunakan Algoritma Laili (2015) mempunyai nilai koefisien korelasi sebesar $82.6 \%$. Hal ini menjelaskan bahwa ada hubungan antara nilai TSS data citra dengan nilai TSS data In Situ sangat kuat.

b. Uji korelasi data lapangan TSS (Total Suspended Solid) dengan data hasil olahan TSS (Total Suspended Solid) Citra Landsat 8 menggunakan Algoritma Budiman (2004) mempunyai nilai koefisien korelasi sebesar 85,3 \%. Hal ini menjelaskan bahwa ada hubungan antara nilai TSS data citra dengan nilai TSS data In Situ sangat kuat. c. Uji korelasi data lapangan TSS (Total Suspended Solid) dengan data hasil olahan TSS (Total Suspended Solid) Citra Landsat 8 menggunakan Algoritma Parwati (2006) mempunyai nilai koefisien korelasi sebesar 84 \%. Hal ini menjelaskan bahwa ada hubungan antara nilai TSS data citra dengan data In Situ sangat kuat.

Berikut adalah grafik uji validasi antara data lapangan dengan data citra:

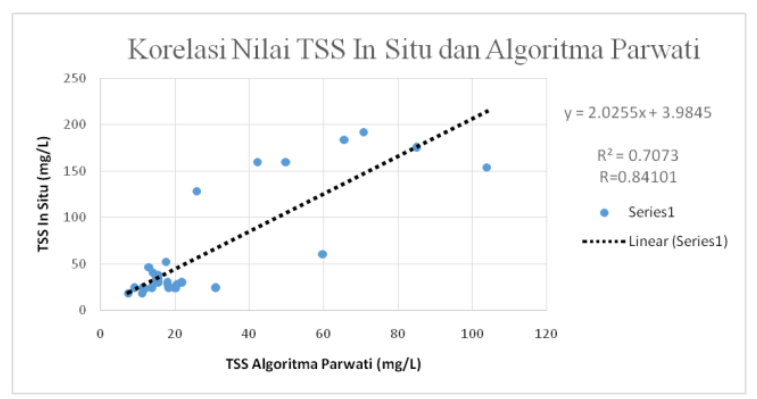

Gambar 2 . Uji Validasi Nilai TSS Algoritma Parwati (2006)

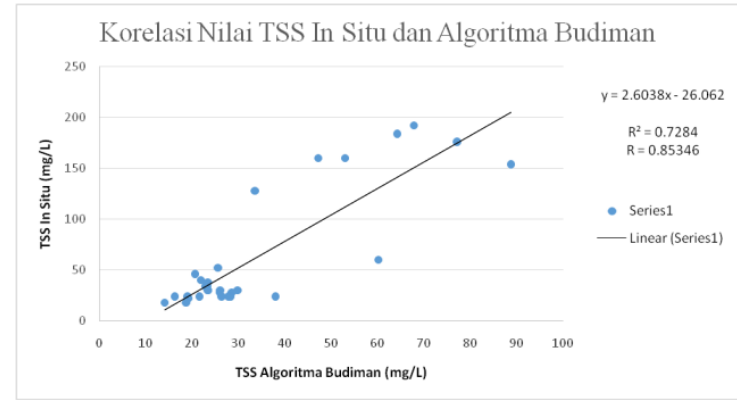

Gambar 3. Uji Validasi Nilai TSS Algoritma Budiman (2004)

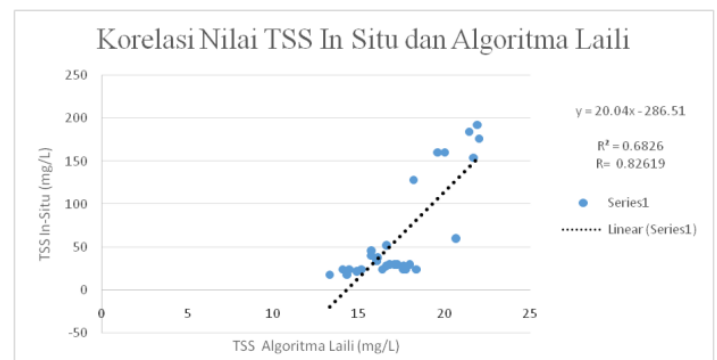

Gambar 4. Uji Validasi Nilai TSS Algoritma Laili (2015)

\section{Analisa Perbandingan Nilai TSS Citra Landsat-8 pada 17 Maret 2017 dengan Data Lapangan.}

Nilai $R^{2}$ yang didapat dari rumus regresi linear menjelaskan bahwa koefisien determinasi dari data citra untuk dapat menggambarkan data di lapangan yang paling baik adalah sebesar $85.3 \%$. 
Dari hubungan ini dijelaskan bahwa sebagian besar TSS di lapangan dapat dijelaskan oleh citra. Dengan demikian nilai yang dianggap berkorelasi sedang sampai sangat kuat apabila nilai koefisien korelasi lebih dari sama dengan 0.4 atau bisa disebut Korelasi kuat (Sarwono, 2006). Untuk perhitungan TSS menggunakan algoritma lainnya memiliki perbedaan yang cukup menonjol antara citra dan data lapangan hal ini dapat disebabkan karena :

a. Perbedaan waktu perekaman citra dan waktu pengambilan data insitu.

Waktu perekaman citra adalah Tanggal 17 Maret 2017 pada pukul 09:35:28 sedangkan waktu pengambilan data lapangan mulai pukul 08.00-15.30 WIB. Dapat dilihat selang waktu dalam pengambilan data insitu. Hal ini dapat mengakibatkan perubahan / dinamika kondisi perairan yang mengakibatkan perubahan nilai dan sebaran TSS

b. Pengaruh radiometrik

Perbedaan nilai TSS citra dan In Situ dapat disebabkan karena pengaruh radiometrik / gangguan perambatan gelombang di udara.

\section{Analisa Status Mutu Air Dengan Metoda Indeks Pencemaran Berdasarkan Nilai TSS}

Berdasarkan nilai korelasi pada pengolahan data diatas didapatkan hubungan yang paling baik adalah algoritma Budiman, maka data hasil pengolahan data digunakan sebagai acuan data untuk menilai status mutu air dengan metoda indeks pencemaran.

\begin{tabular}{cccrr}
\multicolumn{5}{c}{ Tabel 1 Nilai analisa status mutu air } \\
\hline No & \multicolumn{2}{c}{ Koordinat Geografis } & $\begin{array}{r}\text { Indeks } \\
\text { Pencemaran } \\
\text { Data Citra }\end{array}$ & $\begin{array}{r}\text { Indeks } \\
\text { Pencemaran } \\
\text { Data Insitu }\end{array}$ \\
\hline 1 & X & Y & 0,4903349 & 0,6032789 \\
2 & 698856 & 9202332 & 0,57132 & 0,7890492 \\
3 & 699784 & 9199212 & 0,7494797 & 0,7290321 \\
4 & 701244 & 9198726 & 1,05528 & 0,5868794 \\
5 & 702238 & 9198053 & 1,18376 & 0,7398683 \\
6 & 703073 & 9198741 & 0,4178928 & 0,7368973 \\
7 & 702163 & 9199281 & 0,3156489 & 0,4983515 \\
8 & 700784 & 9199842 & 0,4814923 & 0,5535272 \\
9 & 696669 & 9202783 & 0,524154 & 0,7463464 \\
10 & 697194 & 9202399 & 0,5098771 & 0,7885205 \\
11 & 697735 & 9201667 & 0,6383597 & 0,7964867 \\
12 & 698191 & 9201065 & 0,6323814 & 0,913674 \\
13 & 698514 & 9200302 & 0,5220404 & 0,7901075 \\
14 & 699033 & 9199704 & 0,6218435 & 0,6089819 \\
15 & 699319 & 9198951 & 1,34463 & 1,20962 \\
16 & 700162 & 9198583 & 1,98301 & 1,28187 \\
17 & 700974 & 9198342 & 1,72364 & 1,31300 \\
18 & 701602 & 9197914 & 1,51594 & 1,12251 \\
19 & 702226 & 9197527 & 1,43537 & 1,19199 \\
20 & 702672 & 9197961 & 0,8484471 & 0,7630438
\end{tabular}

\begin{tabular}{rrrrr}
21 & 702549 & 9198594 & 0,3628607 & 0,5395545 \\
22 & 702041 & 9199100 & 0,425005 & 0,4916833 \\
23 & 701365 & 9199616 & 0,4307811 & 0,5568884 \\
24 & 700498 & 9199447 & 0,6650662 & 0,7508642 \\
25 & 699928 & 9199964 & 0,5884839 & 0,661435 \\
26 & 699445 & 9200494 & 0,5821843 & 0,6417458 \\
27 & 698983 & 9201033 & 0,58101 & 0,60735 \\
28 & 698489.4 & 9201559 & 0,52134 & 0,68677 \\
29 & 697906.4 & 9202096 & 0,52239 & 0,50681 \\
30 & 696924.8 & 9202778 & 0,46178 & 0,82086 \\
\hline
\end{tabular}

Berdasarkan hasil pengolahan data untuk menentukan status mutu air dengan metoda indeks pencemaran sesuai dengan Keputusan Menteri Negara Lingkungan Hidup Nomor 115 Tahun 2003 Tentang Pedoman Penetuan Status Mutu Air didapatkan hasil rata-rata nilai berada pada rentang nilai $0 \leq$ indeks pencemaran $\leq 1$ yang berati kondisi perairan Pantai Timur Surabaya memenuhi baku mutu atau dalam kondisi baik. Beberapa titik menunjukkan nilai $1 \leq$ indeks pencemaran $\leq 5$ yang menunjukkan perairan dalam kondisi cemar ringan, hal ini perlu diwaspadai karena jika tidak dilakukan penanganan khusus, maka perairan Pantai Timur Surabaya akan semakin tercemar.

\section{Analisa Sebaran TSS}

Dari Gambar 5 dapat dianalisa bahwa algoritma Budhiman nilai dan sebaran TSS di Pantai Timur Surabaya secara visual peta sebaran konsentrasi TSS memiliki rentang nilai antara $1 \mathrm{mg} / \mathrm{l}$ sampai $>30 \mathrm{mg} / \mathrm{l}$, pada pesisir pantai memiliki nilai konsetrasi peta lebih dari $30 \mathrm{mg} / \mathrm{L}$. Hal ini bisa disebabkan karena di daerah penelitian adanya aktivitas manusia dan berdekatan dengan kegiatan pembuangan limbah dari kegiatan rumah tangga yang menyebabkan konsentrasi sedimendasi.

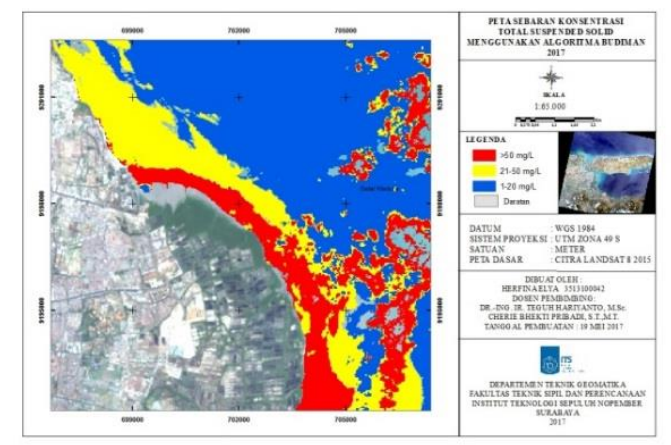

Gambar 5. Peta Sebaran TSS 2017 menggunakan algoritma Budiman 
Dapat dilihat pada Gambar 6 sebaran TSS berdasarkan algoritma Parwati menunjukkan kawasan pesisir memiliki kondisi nilai TSS yang tinggi dikanalingkan dengan perairan yang lebih dalam. Nilai yang tinggi bisa disebabkan karena adanya aktivitas manusia berada pada sekitar kawasan pesisir Pantai Timur Surabaya.

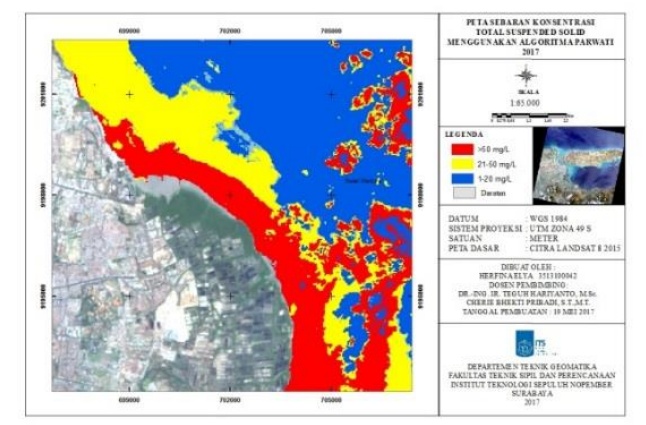

Gambar 6. Peta Sebaran TSS 2017 menggunakan algoritma Parwati

Dapat dilihat pada Gambar 7 sebaran TSS berdasarkan algoritma Laili menunjukkan kawasan pesisir memiliki kondisi nilai TSS yang tinggi dikanalingkan dengan perairan dalam. Nilai yang tinggi bisa disebabkan karena adanya aktivitas manusia berada pada sekitar kawasan pesisir Pantai Timur Surabaya.

Dari peta sebaran TSS tahun 2017 hasil pengolahan citra Landsat 8 menggunakan data insitu dan algoritma Laili, Parwati, Budhiman di atas dapat dianalisa bahwa nilai dan sebaran TSS di Pantai Timur Surabaya secara visual peta sebaran konsentrasi TSS memiliki rentang nilai bervariasi antara $1 \mathrm{mg} / \mathrm{l}$ sampai $>50 \mathrm{mg} / \mathrm{l}$, pada pesisir pantai memiliki nilai konsetrasi peta lebih dari $50 \mathrm{mg} / \mathrm{L}$.

Hal ini bisa disebabkan karena di daerah penelitian dekat dengan kegiatan pembuangan limbah dari kegiatan rumah tangga yang menyebabkan konsentrasi sedimendasi.

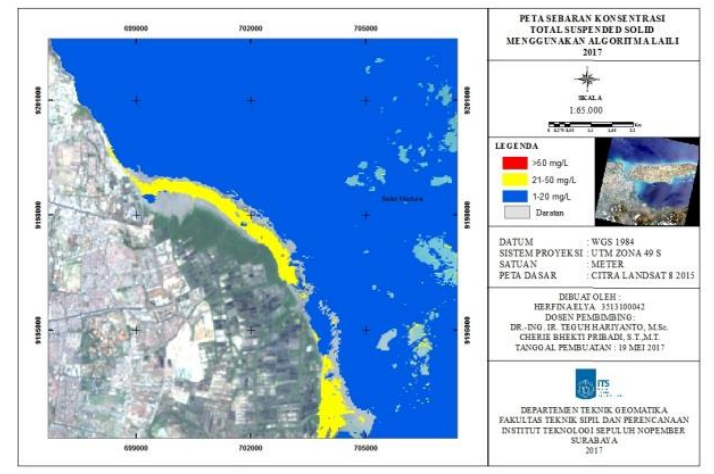

Gambar 7. Peta Sebaran TSS 2017 menggunakan algoritma laili

\section{KESIMPULAN}

Kesimpulan dari penelitian ini adalah sebagai berikut :

a. Dari peta sebaran TSS tahun 2013-2017 hasil pengolahan citra Landsat 8 di atas dapat dianalisa bahwa nilai TSS di Pantai Timur Surabaya menunjukkan peningkatan yaitu 192 $\mathrm{mg} / \mathrm{L}$.

b. Kondisi sebaran TSS pada perairan Pantai Timur Surabaya sejak tahun 2013 sampai tahun 2017 mengalami perubahan setiap tahun karena faktor alam dan perkembangan aktivitas manusia. Kondisi perairan berdasarkan Keputusan Menteri Negara Lingkungan Hidup Lingkungan Hidup Nomor 115 Tahun 2003 Tentang Pedoman Penetuan Status Mutu Air didapatkan hasil rata-rata nilai berada pada rentang nilai $0 \leq$ indeks pencemaran $\leq 1$ yang berati kondisi perairan Pantai Timur Surabaya memenuhi baku mutu atau dalam kondisi baik. Beberapa titik menunjukkan nilai $1 \leq$ indeks pencemaran $\leq 5$ yang menunjukkan perairan dalam kondisi cemar ringan.

c. Uji korelasi data lapangan TSS (Total Suspended Solid) dengan data hasil olahan TSS Citra Landsat 8 tahun 2017 pada tanggal 17 Maret 2017 menggunakan algoritma Syarif Budiman (2004) Sebesar 85,3 \%, algoritma Parwati (2006) sebesar 84,1\%, algoritma Laili (2015) sebesar $82,6 \%$. Nilai $R^{2}$ paling baik dihasilkan dengan menggunakan algoritma Budiman (2004), yakni 85,3\%. Nilai koefiseien 
determinasi yang mendekati satu atau $100 \%$ menunjukkan hubungan yang positif, sebaliknya jika R2 mendekati nol, maka memiliki hubungan jelek. Dengan demikian citra Landsat 8 dapat digunakan untuk menggambarkan kondisi Perairan Pantai Timur Surabaya seperti pada kondisi yang ada di lapangan.

\section{DAFTAR PUSTAKA}

Budiman, S. (2004). Mapping TSM Concentrations From Multi Sensor Satellite Images in Turbid Tropical Coastal Waters of Mahakam Delta Indonesia, Enschede: MSc Thesis ITC Enschede, The Netherlands.

Effendi, H. (2003). Telaah Kualitas Air Bagi Pengelolaan Sumberdaya dan Lingkungan Perairan.Yogyakarta: Kanisius.

Laili, L. J. (2015). Development Of Water Quality Parameter Retrieval Algorithms For Estimating Total Suspended Solids And Chlorophyll-A Concentration Using Landsat-8 Imagery At Poteran Island Water. 55-62.

Lestari, I. B. (2009). 'Pendugaan Konsentrasi Total Suspended Solid (TSS) dan Transparansi Perairan Teluk Jakarta dengan Citra Satelit Landsat'. Skripsi. Bogor: Institut Pertanian Bogor

Parwati, E. Tatik Kartika, Sri Harini, Fany Diah K. (2006). Pemodelan Dinamika Spasial Pengelolaan Lahan Pesisir Kabupaten Berau, Kalimantan Timur Menggunakan Data Inderaja. Laporan Akhir Riset Unggulan Kemandirian Kedirgantaran LAPAN

Saeni, M. S. (2008). Biologi Air Limbah. Bogor: Program Pasca Sarjana IPB.

Sarwono, J. (2006). Metode Penelitian Kuantitatif dan Kualitatif. Yogyakarta :Graha IImu

Siagian, L. 2008. Analisis Tingkat Pencemaran Logam Berat Perairan Laut Belawan. Medan. Lembaga Penelitian Universitas Nommensen.

Wijaya, U dan Kartika, C. (2004). Kombinasi Lumpur Aktif-Membran Untuk Pengolahan Air Limbah Domestik. Surabaya. Tugas Akhir Jurusan Teknik Kimia ITS. 